\title{
The Relationship Between Physical Fitness Levels and Digit Ratio (2D:4D) of High School Students Engaged Actively in Sports
}

\author{
Mustafa Gümüş ${ }^{1}$ Erkut Tutkun ${ }^{2}$ \\ ${ }^{1}$ Department of Physical Education and Sport, Bulent Ecevit University, Zonguldak, Turkey \\ ${ }^{2}$ Faculty of Sport Science, University of Uludag, Bursa, Turkey \\ Correspondence: Erkut Tutkun, Faculty of Sport Science, University of Uludag, Bursa, Turkey.
}

Received: September 10, 2018

Accepted: September 25, $2018 \quad$ Online Published: September 28, 2018

doi:10.11114/jets.v6i10.3613

URL: https://doi.org/10.11114/jets.v6i10.3613

\begin{abstract}
The aim of this study is to examine the association between physical fitness and 2D:4D finger ratio of high school students engaged actively in sports. 23 licensed male athletes and 23 sedentary $(n=46)$ high school students participated in the study voluntarily. The participants age, body weight, body mass index, 2D:4D finger measurement values were recorded and 20 meter shuttle run, 30 meter sprint, sit and reach test, standing long jump and hand grip strength tests were applied on the participants. The data obtained were assessed in SPSS 21 program and the results were assessed at $\mathrm{p}<0.05$ significance level. While the average age of athletes was $15.82 \pm 1.11$ years, the average age of sedentary group was $15.13 \pm 0.96$ years. While statistically significant difference was found between sedentary and athlete groups in terms of $\mathrm{VO}_{2}$ max, right and left hand grip strength and long jump average values $(\mathrm{p}<0.05)$, no statistically significant difference was found between speed and flexibility measurement results ( $p>0.05)$. When the 2D:4D averages of sedentary and athlete groups were compared, statistically significant difference was found between right hand averages $(\mathrm{p}<0.05)$. When right and left hand 2D:4D was compared, no statistically significant difference was found in sedentary group ( $>0.05)$, while significant difference was found in athletes $(p<0.05)$. Statistically significant difference was found between 2D:4D averages of both hands with all physical fitness parameters $(\mathrm{p}<0.05)$. In the present study, finger ratio of the groups were found to be associated with some motoric and functional dominance parameters.
\end{abstract}

Keywords: digit ratio, 2D:4D, physical fitness, high school student

\section{Introduction}

Physical fitness includes cardiorespiratory endurance, muscular endurance, muscular force, muscle strength, speed, flexibility, balance, reaction time and body composition (Özer, 2001). For this reason, physical fitness cannot be assessed by a single test and consists of multiple distinct aspects such as balance, flexibility, speed of limb movement, sprinting speed, endurance and static, explosive, functional, and trunk strength as is evidenced by factor analyses e.g. (Simons et al., 1990). Determination of physical fitness levels is possible especially through sportive achievement skills reaching the top level. For this reason, talents should be determined especially in early ages and suitable methods should be determined to find out talented athletes.

Many children strive to attain excellence in sport. However, although talent identification and development programs have gained popularity in recent decades, there remains a lack of consensus in relation to how talent should be defined or identified and there is no uniformly accepted theoretical framework to guide current practices (Vaeyens et al., 2008). In addition, it is possible to speak of the lack of talent identification practices especially for school children. New researches and new talent markers on this issue attract researchers' interest. One of these research topics is the association between performance and 2D:4D. A great number of researches have been conducted on this topic led by Manning (Manning et al., 1998); however, it is not yet possible to talk about a standard approach.

2D:4D ratio is the ratio of second digit (index finger (2D)) to the fourth digit (ring finger (4D)) length (Çelenk, 2011). Low 2D:4D ratio is reported to be associated with being exposed to more testosterone hormone in prenatal period, while high 2D:4D ratio is reported to be associated with being exposed to more oestrogen hormone (Lutchmaya et al., 2004; Manning and Fink, 2008; Bennett et al., 2010). Prenatal testosterone is reported to have a negative association with 2D:4D, while prenatal oestrogen is reported to have a positive association with 2D:4D (Manning et al., 1998). In addition, it is thought that there is a negative association between 2D:4D and sportive performance (Manning and Taylor, 
2001). Similarly, a great number of studies have shown that 2D:4D ratio has a negative correlation with physical fitness (Manning and Taylor, 2001; Manning, 2002; Pauel et al., 2006; Bennett et al., 2010; Longman et al., 2011). In their study, Manning and Taylor (2001) found that 2D:4D ratios of professional football players were significantly lower when compared with the control group. In addition, international athletes were found to have lower 2D:4D ratio when compared with other athletes. Again, a significant negative association was found between 2D:4D and sport activities such as rugby (Bennett et al., 2010), skiing (Manning, 2002), and football (Manning and Taylor, 2001) in terms of performance.

Considering the facts that the ratio of finger lengths to each other are determined in the mother's womb and do not change in adolescence or adulthood (Çelik et al., 2010) and that it is important to identify talent at an early age besides physical fitness in order to reach top level performance, the significance of the association between 2D:4D ratio and athletes' physical fitness levels will be better understood. It is clear that if an association is found between 2D:4D ratio and physical fitness levels, this will provide a new perspective and contribution to studies conducted about talent identification especially in Turkey and to talent identification programs conducted in schools. The aim of this study is to examine the association between physical fitness and 2D:4D finger ratios of high school students engaged actively in sport.

\section{Method}

\subsection{Participant Characterics}

23 licensed amateur male soccer players and who were attending school teams and 23 sedentary high school students in Samsun participated in the study voluntarily. The participants' body weight was measured with a $0.1 \mathrm{~kg}$ precision electronic scale, while their height was measured with a $0.01 \mathrm{~cm}$ precision digital stadiometer.

\subsection{Measures and Tests}

\subsubsection{Body Mass Index}

Body weight / Height (m) ${ }^{2}$ formula was used

\subsubsection{D:4D Ratio Measurement}

The measurement of the area between the pulp and the basal line on the proximal part of the finger on palmar side of the hand was conducted by using a Vernier caliper that can measure up to $0.05 \mathrm{~mm}$. The measurements were made twice by the same person for reliability and they were expressed in centimetre. In order to find out the ratio, the length of second digit was divided to the length of the fourth digit.

\subsubsection{Meter Shuttle Run Test}

In this test, which starts with a walking tempo and ends with a sprint, the participants were made to reach from one line to another without being late with each beep sound from a $20 \mathrm{~m}$. shuttle run test cd recorded previously in line with the protocol within a 20 meter distance between two lines. In each test area, 4 students were made to run based on similar age, weight and height characteristics. Each time they reached the line, they were made to touch the line. The samples were made to run with a speed in line with the repetition interval of recorded signal sounds and they were motivated to keep running. The runs of participants who were not able to catch the beep sound twice successively were ended. The phase the sample was stopped was recorded as the test result. $\mathrm{VO}_{2}$ max value was recorded as $\mathrm{ml} / \mathrm{kg} /$ minute according to the result obtained.

\subsubsection{Metre Sprint Test}

Electronic and telemetric chronometer that can record one hundredth of a second was used to find out 30 meter sprint. The test repeated two times and the best result was recorded

\subsubsection{Sit and Reach Test}

The upper surface of a $32 \mathrm{~cm}$ high and $35 \mathrm{~cm}$ long box was divided into centimetres. The participants sat on the floor, stretched their legs and placed the soles of their feet against the box after removing shoes. Later, they reached forward over the box as far as possible from the trunk (waist and hip). The farthest point reached by fingers was measured in $\mathrm{cm}$. and at the end of three repetitions the best degree was taken.

\subsubsection{Standing Long Jump}

The participants were made to jump from behind the starting line with their arms behind, in squat position with both feet parallel to each other and by moving their arms up to the front. The distance between the starting line and the place where the participant touched the closest to the line was measured in $\mathrm{cm}$. The participants were asked to stand with both feet slightly apart without falling forward or backward. The test was conducted twice and the better value was recorded. 


\subsubsection{Hand Grip Strength}

Hand grip strength was measured with Jamar hydraulic dynamometer (Sammons Preston, USA). The measurement was started from the dominant side. The measurement was conducted when the athlete was in sitting position with $90^{\circ}$ flexion of the forearm without taking support from the trunk. The measurement was repeated 3 times successively and the average value was used. The values were recorded in kilogram.

\subsection{Analysis of Data}

The obtained data has been evaluated in the SPSS 21 software program. The mean and standard deviations of all data has been calculated; in the determination of the difference between the averages of the athletes and sedentary groups, the Independent Samples T-Test has been used. In the determination of the statistical relationship between physical fitness and 2D:4D, the Pearson Correlation Coefficient analyses have been used.

\section{Results}

In the sedentary group, average age was 15,13 years, average height was $156,65 \mathrm{~cm}$, average weight was $48,39 \mathrm{~kg}$ and average BMI was $19,72 \mathrm{~kg} / \mathrm{m}^{2}$, while the same values were found as 15,82 years, $150,17 \mathrm{~cm}, 42,21 \mathrm{~kg}, 18,68 \mathrm{~kg} / \mathrm{m}^{2}$, respectively in the athlete group.

Table 1. Measurement parameters of the study group

\begin{tabular}{|c|c|c|c|c|c|c|}
\hline & Group & $\mathbf{n}$ & $x$ & Sd & $\mathbf{t}$ & $\mathbf{p}$ \\
\hline \multirow{2}{*}{ Age } & Sedentary & 23 & 15,13 & ,967 & \multirow{2}{*}{$-2,261$} & \multirow{2}{*}{,029 } \\
\hline & Athlete & 23 & 15,82 & 1,114 & & \\
\hline \multirow{2}{*}{ Height (cm) } & Sedentary & 23 & 156,65 & 8,331 & \multirow{2}{*}{2,880} & \multirow{2}{*}{, 006} \\
\hline & Athlete & 23 & 150,17 & 6,853 & & \\
\hline \multirow{2}{*}{ Weight (kg) } & Sedentary & 23 & 48,39 & 7,346 & \multirow[b]{2}{*}{3,319} & \multirow[b]{2}{*}{, 002} \\
\hline & Athlete & 23 & 42,21 & 5,062 & & \\
\hline \multirow{2}{*}{ BMI $\left(\mathrm{kg} / \mathrm{m}^{2}\right)$} & Sedentary & 23 & 19,72 & 2,652 & \multirow{2}{*}{1,661} & \multirow{2}{*}{, 104} \\
\hline & Athlete & 23 & 18,68 & 1,433 & & \\
\hline \multirow{2}{*}{30 meter (sec) } & Sedentary & 23 & 5,40 & ,351 & \multirow{2}{*}{1,590} & \multirow{2}{*}{, 119} \\
\hline & Athlete & 23 & 5,22 & ,432 & & \\
\hline \multirow{2}{*}{$\mathrm{VO}_{2} \mathrm{max}(\mathrm{ml} / \mathrm{kg} / \mathrm{minute})$} & Sedentary & 23 & 43,77 & 4,800 & \multirow{2}{*}{$-3,848$} & \multirow{2}{*}{, 000} \\
\hline & Athlete & 23 & 49,21 & 4,792 & & \\
\hline \multirow{2}{*}{ Grip strength (right) } & Sedentary & 23 & 24,56 & 4,822 & \multirow{2}{*}{$-4,421$} & \multirow{2}{*}{,000 } \\
\hline & Athlete & 23 & 31,21 & 5,367 & & \\
\hline \multirow{2}{*}{ Grip strength (left) } & Sedentary & 23 & 24,65 & 4,696 & \multirow{2}{*}{$-3,686$} & \multirow{2}{*}{,001 } \\
\hline & Athlete & 23 & 29,04 & 3,254 & & \\
\hline \multirow{2}{*}{ Flexibility (cm) } & Sedentary & 23 & 19,13 & 3,034 & \multirow{2}{*}{$\begin{array}{l}1,823 \\
1,823 \\
\end{array}$} & \multirow{2}{*}{,075 } \\
\hline & Athlete & 23 & 17,13 & 4,299 & & \\
\hline \multirow{2}{*}{ Standing long jump (cm) } & Sedentary & 23 & 161,21 & 9,055 & \multirow[b]{2}{*}{$-3,666$} & \multirow{2}{*}{,001 } \\
\hline & Athlete & 23 & 171,13 & 9,284 & & \\
\hline \multirow{2}{*}{ 2D:4D right } & Sedentary & 23 & ,92 &, 087 & \multirow{2}{*}{$-2,331$} & \multirow{2}{*}{, 024} \\
\hline & Athlete & 23 & ,86 &, 070 & & \\
\hline 2D:4D left & Sedentary & 23 & ,92 &, 072 & & \\
\hline 2D:4D left & Athlete & 23 & ,93 &, 063 & ,889 &, 379 \\
\hline
\end{tabular}

p $<\mathbf{0 . 0 5}$

When sedentary and athlete groups were compared, while statistically significant difference was found between $\mathrm{VO}_{2}$ max, right and left hand grip strength and long jump average values $(\mathrm{p}<0.05)$, no statistically significant difference was found between speed and flexibility measurement results ( $p>0.05)$. When 2D4D averages of sedentary and athlete groups were compared, statistically significant difference was found in right hand averages $(p<0.05)$.

Table 2. Comparison of right hand 2D:4D and left hand 2D:4D averages of sedentary and athlete groups

\begin{tabular}{|c|c|c|c|c|c|c|}
\hline & Parameters & $\mathbf{n}$ & $x$ & sd & $\mathbf{t}$ & $\mathbf{p}$ \\
\hline \multirow{2}{*}{ Sedentary } & Right hand 2D:4D & 23 & ,92 & ,087 & \multirow{2}{*}{, 085} & \multirow{2}{*}{ 933 } \\
\hline & Left hand 2D:4D & 23 & ,92 & 072 & & \\
\hline \multirow{2}{*}{ Athlete } & Right hand 2D:4D & 23 &, 86 &, 070 & \multirow{2}{*}{$-3,945$} & \multirow{2}{*}{, 001} \\
\hline & Left hand 2D:4D & 23 & ,93 &, 063 & & \\
\hline
\end{tabular}

$\mathrm{p}<0.05$

No statistically significant difference was found when right hand 2D:4D and left hand 2D:4D of the sedentary group were compared ( $p>0.05)$, while statistically significant difference was found in athletes $(p<0.05)$. In the athlete group, right hand 2D:4D ratios are lower than left hand 2D:4D ratios. 
Table 3. Comparison of 2D:4D ratios and physical fitness tests of the athlete group

\begin{tabular}{c|c|c|c|c|c|c|c|c}
\hline \multirow{2}{*}{ Parameters } & \multirow{2}{*}{} & & \multirow{2}{*}{$\mathbf{V O}_{2} \mathbf{m a x}$} & \multirow{2}{*}{$\mathbf{3 0 m}$} & \multirow{2}{*}{ Flexibility } & \multirow{2}{*}{$\begin{array}{c}\text { Standing } \\
\text { long jump }\end{array}$} & \multicolumn{2}{|c}{ Grip strength } \\
\hline \multirow{2}{*}{ Right hand 2D:4D } & 23 & $\mathrm{r}$ & $-0.206^{*}$ & $-0.104^{*}$ & $0.192^{*}$ & $0.249^{*}$ & $0.281^{*}$ & $0.117^{*}$ \\
\cline { 2 - 11 } & 23 & $\mathrm{p}$ & $\mathbf{0 . 0 1 1}$ & $\mathbf{0 . 0 1 8}$ & $\mathbf{0 . 0 4 3}$ & $\mathbf{0 . 0 2 2}$ & $\mathbf{0 . 0 1 2}$ & $\mathbf{0 . 0 4 6}$ \\
\hline \multirow{2}{*}{ Left hand 2D:4D } & 23 & $\mathrm{r}$ & $0.52^{*}$ & $-0.03^{*}$ & $-0.043^{*}$ & $0.148^{*}$ & $-0.139^{*}$ & $-0.139^{*}$ \\
\cline { 2 - 10 } & 23 & $\mathrm{p}$ & $\mathbf{0 . 0 0 1}$ & $\mathbf{0 . 0 4 8}$ & $\mathbf{0 . 0 4 7}$ & $\mathbf{0 . 0 3 8}$ & $\mathbf{0 . 0 1 1}$ & $\mathbf{0 . 0 2 4}$ \\
\hline
\end{tabular}

$\mathrm{p}<0.05$

Statistically significant difference was found between 2D:4D averages of both hands with all physical fitness parameters $(\mathrm{p}<0.05)$.

\section{Discussion}

In the present study, associations between participants' physical fitness and 2D:4D ratios were discussed.

In our study, when the sedentary group and athlete group was compared, statistically significant difference was found between $\mathrm{VO}_{2} \mathrm{max}$, right and left hand grip strength and long jump average values, while no significant difference was found between sprint and flexibility measurement results. At the same time, athletes' grip strength and $30 \mathrm{~m}$. sprint averages, $\mathrm{VO}_{2} \max$, standing long jump and flexibility values were found to be better than the non-athlete group. In the study athletes $30 \mathrm{~m}$. sprint averages $5,22, \mathrm{VO}_{2}$ max averages 49,21 , right hand grip strength averages 31,21 , left hand grip strength averages 29,04, flexibility averages 17,13 , standing long jump averages 171,13 was determined. Gümüş and Akalın (2016), was found the dominant hand grasp force of sportsmen $57.6 \pm 15.0$ for right-handed, $53.5 \pm 7.7$ for left-handed, these values for nondominant hand were $46.5 \pm 12.4$ and $47.5 \pm 9.2$ respectively for national sportsmen. Acar and Tutkun (2017), was found 30 meter sprint $(4,99 \pm 1,12$ and 5,95 $\pm 1,43 \mathrm{sec})$, right hand grip $(26,3 \pm 3,2$ and 17,3 $\pm 1,9$ $\mathrm{kg}$ ), left hand grip $24,0 \pm 2,5$ and $15,2 \pm 2,1 \mathrm{~kg}$. for 14-year-old footballer and sedentary groups respectively. Also they found that grip strength, $30 \mathrm{~m}$. sprint averages and flexibility values of 14 -year-old footballers were better when compared with non-athlete groups, while Günay et. al. (2011), found that sit and reach test averages of 13-year-old athletes were found to be better when compared with a sedentary group of the same age group. When hand skill, strength, speed and flexibility average values of active athletes are taken into consideration, it is an expected result for hand related parameters of athletes to be higher than sedentary groups. Eler and Acar (2018), 10-12 year old boys who regularly attended physical education and sports lessons participated in their study $(n=240)$. The students were divided into two groups and the first group had regular rope jump training exercises for 3 days a week for 10 weeks, and the control group only continued physical education and sports lessons. When the measurement differences between pre-test and post-test were compared according to the groups, it was determined that weight, body fat ratio, $20 \mathrm{~m}$ sprint, $\max \mathrm{VO}_{2}$ and leg strength measurements were significantly different in favor of rope jump group $(\mathrm{p}<0.05)$. According to these results, it can be said that as a result of doing sport, motoric characteristics of children in growth and development periods such as strength, speed and flexibility develop positively.

When 2D:4D averages of sedentary and athlete groups were compared, statistically significant difference was found in right hand averages. Athletes' right hand 2D:4D averages were found as 0.86 and left hand 2D:4D averages were found as 0.93 , while sedentary group's right hand 2D:4D averages were found as 0.92 and left hand 2D:4D averages were found as 0.92. In their study, Giffin et al., (2012), found the 2D:4D ratios of varsity athletes as 0.97 , while 2D:4D ratios of non-varsity athletes was 0.99 and they reported that varsity athletes had significantly lower ratios than their non-varsity peers. Keshavarz et al., (2017), found that right hand 2D:4D average of elite Greco-Roman wrestlers was 0.93, while their left hand 2D:4D average was 0.93; right hand 2D:4D average of non-elite Greco-Roman wrestlers was 0,97, while their left hand 2D:4D average was 0,98 and right hand 2D:4D average of control group was 0,98, while their left hand 2D:4D average was 0,99 . When elite wrestlers and non-elite wrestlers and control group were compared separately, statistically significant difference was found between 2D:4D averages of both hands ( $\mathrm{p}=0.0001)$. Based on these results, it can be said that there are differences between 2D:4D averages of groups doing sports and those not doing sports. However, significant difference was found only in right hand averages in our study. Giffin et al., (2012), made assessment by using the averages of both hands and reported significant difference in their study. Keshavarz et al., (2017), found significant difference in 2D:4D averages of both hands. It is thought that the difference between digit ratios can be resulting from endocrine system or genetic factors. When the literature is reviewed, statements and results can be found which report that different results about 2D:4D ratios can be resulting from different reasons. For example, Manning and Hill (2009), found that low 2D:4D ratio associated with prenatal testosterone (high prenatal testosterone) was associated with high sportive performance. For this reason, it is not possible to argue exactly for sure that 2D:4D averages are a determining factor in athletes. In addition, according to the results of all studies, it is not possible to talk about a standard average in 2D:4D ratios. This difference can be associated with the fact that the studies were conducted in different countries. Manning et al., (2000), found significant differences in 2D:4D lengths between populations of different ethnicities. 
When right hand 2D:4D and left hand 2D:4D average values were compared in the sedentary group, no statistically significant difference was found, while significant difference was found in athletes. Statistically significant difference was found between right and left hand 2D:4D ratios in elite male swimmers in Acar and Eler (2018)'s study and in male taekwondo athletes in Kim [23]'s study ( $<<0.05)$. In the present study and in Kim (2016)'s study, left hand 2D:4D ratios are lower when compared with right hand 2D:4D ratios. According to these results, the difference between both hand 2D:4D averages of athletes can be associated with digit ratios being a determiner of sportive performance; however, according to these results, it is not possible to say which hand's lower 2D:4D averages can be predicted as a determiner of performance. This difference may be associated with ethnic characteristics.

In athlete group statistically significant difference was found between 2D:4D averages of both hands with all physical fitness parameters. Hill et al., (2012), $(\mathrm{n}=41)$ found no significant relation between maximal oxygen uptake and right or left 2D:4D. Acar and Eler (2018), found negative correlation between right and left hand 2D:4D and both dominant and non-dominant hand grip strength of elite men swimmers. Eler and Eler (2018), also found negative correlation between right and left hand 2D:4D and both dominant and non-dominant hand grip strength of men elite handball players. In their study, Fink et al., (2006), found significant difference between 2D:4D ratio and hand grip strength in men ( $\mathrm{n}=140$ ). Manning and Hill (2009), found that 2D:4D ratio of the right and left hand was negatively related to sprinting speed over $20 \mathrm{~m}, 30 \mathrm{~m}, 40 \mathrm{~m}$ and $50 \mathrm{~m}$ in a sample of teenage boys. Researchers generally found significant differences but Hill et al., (2012) found no significant relation in their study. According to these results, it cannot be said for sure that 2D:4D averages have an influence on physical fitness parameters.

As a conclusion, it can be said that health and performance related physical fitness states of male high school students doing sports are in general better than their peers who are not doing sport and that participation in sportive activities has positive influences on physical fitness levels of this age group. It can be said that finger ratios or lengths are associated with some motoric and functional dominance parameters; however, it is not possible to say from the results of the present study that they are determiners of physical performance and physical fitness. For future studies, comparing 2D:4D ratios and physical fitness measurements of individuals from different ethnicities with different procedures and different approaches can contribute to healthier results. It is thought that studies conducted on athletes and sedentary groups will be more effective in showing the distinctiveness of discussing sporting performance together with genetic, biochemical and psychological findings.

\section{References}

Acar, H., \& Eler, N. (2018). The relationship of digit ratio (2D:4D) with cerebral lateralization and grip strength in elite swimmers. Journal of education and training studies. 6(4), 84-89. https://doi.org/10.11114/jets.v6i4.3040

Acar, H., \& Tutkun, E. (2017). Examination of some physical fitness characteristics in 13-14 year old footballers. Acta Scientiae et Intellectus, 3(5), 35-44.

Bennett, M., Manning, J. T., Cook, C. J., \& Kilduff, L. P. (2010). Digit ratio (2D:4D) and performance in elite rugby players.J Sports Sci. 28(13), 1415-1421. https://doi.org/10.1080/02640414.2010.510143

Çelenk, Ç. (2011). Farklı Branşlardaki Elit Sporcuların 2.ve 4. (2D:4D) Parmaklarının Oranının Sportif Performansa Etki Eden Bazı Biyokimyasal ve Endokrinolojik Parametrelerle İlişkisi. Gazi Üniversitesi, Sağlık Bilimleri Fakültesi, Doktora Tezi, Ankara,

Çelik, A., Aksu, F., Tunar, M., Daşdan Ada, E. N., \& Topaçoğlu, H. (2010). Master atletlerin fiziksel Performans düzeylerinin eldeki parmak oranlarıyla ilişkisi, DEÜ Tip Fakültesi Dergisi, 24, 5-10.

Eler, N., \& Acar, H. (2018). The effects of the rope jump training program in physical education lessons on strength, speed and $\mathrm{vo}_{2} \mathrm{max}$ in children. Universal Journal of Educational Research, 6(2), 340-345. https://doi.org/10.13189/ujer.2018.060217

Eler, N., \& Eler, S. (2018). 2D: 4D, Lateralization and Strength in Handball Players. Journal of Education and Training Studies, 6(5), 170-178. https://doi.org/10.11114/jets.v6i5.3220

Fink, B., Thanzami, V., Seydel, H., \& Manning, J. T. (2006). Digit ratio and hand-grip strength in German and Mizos men: cross-cultural evidence for an organizing effect of prenatal testosterone on strength. Am. J. Hum. Biol., 18(6), 776-782. https://doi.org/10.1002/ajhb.20549

Giffin, N. A., Kennedy, R. M., Jones, M. E., \& Barber, C. A. (2012). Varsity athletes have lower 2D:4D ratios than other university students. J. Sports Sci., 30, 135-138. https://doi.org/10.1080/02640414.2011.630744

Gümüş, M., \& Akalın, T. C. (2016). The Hand Preference of the Natıonal Sportsmen and Evaluation of The Grasp Forces, International Journal of Academic Research, 8(6), 45-50. https://doi.org/10.7813/2075-4124.2016/8-6/A.5

Günay, M., Cigerci, A. E., \& Aksen, P. (2011). The Evaluation Of Some Physical And Motor Features Of The Female 
And Male Students Aged 12-14 Who Participated In Sports Or Not. Bulletin of the Transilvania University of Brasov Series VIII: Art. Sport, 4(53).

Hill, R., Simpson, B., Millet, G., Manning, J., \& Kilduff, L. (2012). Right-left digit ratio (2D:4D) and maximal oxygen uptake. J. Sports Sci., 30(2), 129-134. https://doi.org/10.1080/02640414.2011.637947

Keshavarz, M., Bayati, M., Farzad, B., Dakhili, A., \& Agha-Alinejad, H. (2017). The Second to Fourth Digit Ratio in Elite and Non-Elite Greco-Roman Wrestlers. Journal of Human Kinetics, 60, 145-151. https://doi.org/10.1515/hukin-2017-0097

Kim, B. (2016). A Study of the Second Digit to Forth Digit Ratio targeting Taekwondo Athletes. Indian Journal of Science And Technology, 9(25). https://doi.org/10.17485/ijst/2016/v9i25/97153

Longman, D., Stock, J. T., \& Wells, J. C. (2011). Digit ratio (2D:4D) and rowing ergometer performance in males and females, Am. J. Phys. Anthropol., 144(3), 337-341. https://doi.org/10.1002/ajpa.21407

Lutchmaya, S., Baron-Cohen, S., Raggat, P., Knickmeyer, R., \& Manning, J. T. (2004). 2nd to 4th digit ratios, fetal testosterone and estradiol. Early Human Development, 77, 23-28. https://doi.org/10.1016/j.earlhumdev.2003.12.002

Manning, J. T., \& Hill, M. R. (2009). Digit ratio (2D: 4D) and sprinting speed in boys. American journal of human biology, 2l(2), 210-213. https://doi.org/10.1002/ajhb.20855

Manning, J. T. (2002).The ratio of 2nd and 4th digit length and performance in skiing. J. Sports Med. Phys. Fitness, 6, 211-215.

Manning, J. T., \& Fink, B. (2008). Digit ratio (2D:4D), dominance, reproductive success, asymmetry, and sociosexuality in the BBC Internet Study. American Journal of Human Biology, 20(4), 451-461. https://doi.org/10.1002/ajhb.20767

Manning, J. T., \& Taylor. (2001). Second to fourth digit ratio and male ability in sport: implications for sexual selection in humans Evol. Hum. Behav., 22, 61-69. https://doi.org/10.1016/S1090-5138(00)00063-5

Manning, J. T., Barley, L., Walton, J., Lewis-Jones, D. I., Trivers, R. L., Singh, D. et al. (2000). The 2nd:4th digit ratio, sexual dimorphism, population differences, and reproductive success: Evidence for sexually antagonistic genes? Evolution and Human Behavior, 21, 163-183. https://doi.org/10.1016/S1090-5138(00)00029-5

Manning, J. T., Scutt, D., Wilson, J., \& Lewis-Jones, D. I. (1998). The Ration of 2. To 4. Digit Length: a prediditor of sperm numbers and concentrations of testosterone, luteinizing hormone and oestrogen. Human Repord, 13(11), 3000-3004. https://doi.org/10.1093/humrep/13.11.3000

Özer, K. (2001). Fiziksel uygunluk. Nobel Yayın Dă̆ıtım, Ankara,

Paul, S. N., Kato, B. S., Hunkin, J. L., Vivekanandan, S., \& Spector, T. D. (2006). The big finger: the second to fourth digit ratio is a predictor of sporting ability in women. British Journal of Sports Medicine, 40, 981-983.

Simons, J., Beunen, G. P., Renson, R., Claessens, A. L M., Vanreusel, B., et al. (1990). Growth and fitness of Flemish girls: the Leuven Growth Study. Champaign, Il.: Human Kinetics. 173.

Vaeyens, R., Lenoir, M., Williams, A. M., \& Philippaerts, R. M. (2008). Talent identification and development programmes in sport. Sports medicine, 38(9), 703-714. https://doi.org/10.2165/00007256-200838090-00001

\section{Copyrights}

Copyright for this article is retained by the author(s), with first publication rights granted to the journal.

This is an open-access article distributed under the terms and conditions of the Creative Commons Attribution license which permits unrestricted use, distribution, and reproduction in any medium, provided the original work is properly cited. 